\title{
身体性に注目した空間体験の図式表現方法に関する研究 STUDY ON GRAPHICAL REPRESENTATION OF SPACE EXPERIENCE FOCUSING ON THE PHYSICALITY
}

\author{
福田隼 登*, 藤 井晴 行** \\ Hayato FUKUDA and Haruyuki FUJII
}

\begin{abstract}
The objective of this study is to represent the characteristic of the experience of space, such as a building or a garden, by the graphical expression of the schema framing the space. Particularly, we pay attention to the relations between the space and the person who experience there. The extracted characteristic of the experience of space would be able to be applied to new space design. And, we should be able to understand and explain the experience of space by the schema. This paper proposes a method of schematizing the characteristic of the experience of space and the schemata that are extracted from the experiences of the cozy garden sequence by using this method.
\end{abstract}

Keywords : Physicality, Experience of space, Schema, Sequence, Garden, Narrative 身体性，空間体験，図式，シークエンス，庭園，ナラティブ

\section{1. はじめに}

建築や庭園などの空間体験を図式化して空間体験の特徵を表現す ることを目的とする。特に, 体験主体と空間の関係に注目する。空 間体験の核となるものごとを, 図式として抽象化して表現すること によって，ある場所における空間体験のメカニズムを新たな空間の デザインに適用したり，既存の空間の理解と説明に適用したりする ことが可能になると考えている。いわば，空間構成を身体との関係 によって捉える一般法則の模索である。本論では, その第一歩とし て実施した心地よいという庭園空間の体験を図式表現する。

\section{2. 既往研究と本研究の関係}

材野ら ${ }^{1)}$ は, 短調気味な街路構成の中で豊かなシークエンス景観 を形成することを目的とし, 豊かなシークエンス景観を得られるこ とで知られる 3 つの回遊式庭園を対象に, 2 通りの方法で写真を定 間隔で撮りながら歩いた。ひとつは経路の向きに沿った写真（基本 構造シークェンス景観), もうひとつは実際の視線の向きの写真 (行 動シークエンス景観）とし，これらの写真に写るものの面積の割合 で開放度とインパクト度を測り, 比較分析している。開放度は開放 的空間構成要素（空, 大地, 池などの水平部分）の写真に占める面 積の割合であり, インパクト度は自然系インパクト構成要素（目立 つ樹木, 大きい高低差, 池など）と人工系インパクト構成要素（建 物, 門, 橋, 灯篭など）の写真に占める面積の割合である。この結 果, 開放度とインパクト度がある庭園においては相互補完的性格を 持っていること, 基本構造シークエンス景観の開放度やインパクト
度の值が極端に高くなるとそれらを縮小する方向に行動する傾向が 有ること, また基本構造シークエンス景観で変化の少ない区間は変 化を求める方向に行動することなどが明らかとなった。本研究の目 的は，心地よいと感じるシークエンスの空間体験の特徽を図式化す るという点で材野らと異なる。また本研究では空間体験を静止画で はなく頭にビデオを装着し動画で記録したので，動画に映るものは 行動シークエンス景観であり基本構造シークエンス景観ではない。 また，動画記録の他，五感で得られる情報を言語表現し分析すると いう手法をとる。

横山ら ${ }^{2 \cdot 3 \cdot 4)}$ は，人が空間を認知する際の空間図式の一端を明 らかにすることを目的とし，文献 2 では二つの空間の重なり方と視 点の位置の関係から数学的に考えられる 4 つの図式がスケッチマッ プの実験から実際に抽出することができたることを確認した。また， 実験の考察から連続と分断という図式も導かれた。文献 3 では被験 者に平面図から空間を想起させて図で表現させるという実験を行い, 包含関係と順序関係という図式があることを確認した。文献 4 では, 不完全な情報の文章から被験者が各自の図式を用いて空間を想起し 平面図にするとき，部屋同士の位置の相互関係に方位に関する共通 性があり，そこから方位の図式を見出した。横山らは論理的な連続 関係，分断関係，包含関係，順序関係，方位概念の図式を確認した が，その他に実体的な関係があり得るため，本研究では体験する人 の身体を中心に行う。

ノルベルグ・シュルツ5) は, 建築的空間は体験される空間であり 人間とその知覚作用に結びついているとし，実存的空間を比較的安
* 東京工業大学大学院理工学研究科建築学専攻 博士前期課程

** 東京工業大学大学院理工学研究科建築学専攻 准教授·工博
Graduate Student, Dept. of Architecture, Tokyo Institute of Technology

Prof., Dept. of Architecture, Tokyo Institute of Technology, Dr. Eng. 
定した知覚的シェマ (schema) の体系と定義している。実存的空間 は自己中心的であり絶えず変化する。また, 建築的空間に実存的空 間を取り入れ，建築的空間を考えるうえで実存的空間が重要となる と主張している。実存的空間を構成する関係として, 中心と場所, 方向と通路, 区域と領域という関係を挙げている。本研究は空間を 体験する主体と空間構成要素の関係に関心があるので, 中心と場所 の関係を踏まえ, 体験主体を空間図式の中心に据えることにする。

シールは, 環境デザインと環境研究は環境を動き回る主体の経験 を踏まえてなされる心゙きであるとの主張に基づいて, 環境の経験の シークエンスを生活全体の文脈に関連づけて記述するノーテーショ ン手法を提案している ${ }^{6)}$ 。これに対して, 本研究では, 空間体験に は体験主体の経験に影響される固有の側面と身体と環境との関係と いう体験主体間で共通する側面とがあるとの仮定にもとづき, 体験 主体が注目する体験主体の行為を体験主体自身が観測し, 身体に結 びつけて言語表現する。

\section{3. 研究方法}

体験主体が心地よいと感じる空間体験を, 身体と物的環境との位 置関係, 主体の移動や身体動作, 印象などを記した文章によって表 現する。その文章, 体験を記録したビデオや写真から, 主体と物的 環境の位置関係に着目して心地よいと感じる空間の図式を抽出する (図式表現の方法は手順 1 で詳しく示寸)。このようにして得られた 個々の心地よい空間体験の図式を, 文章中の単語出現数の類似性に 注目してグルーピングする (手順 2)。グループ毎に共通する図式の 要素を抽出する（このようにして得られた図式を核図式と呼ぶ）(手 順 3 )。核図式の有効性を，基礎資料に基づき検討する。

\section{手順 1：空間体験の図式表現}

心地よいと感じる空間を意識しながら庭園や建築内外を回遊する。 心地よいと感じるものごとを体験したとき, 身体の動きや印象, 情 況などを写真, メモ, スケッチ, ビデオを用いて記録する。ビデオ には, 回遊全過程において視界に入るものごとを記録する(画角 120 度のヘッド・マウント・ビデオ・カメラを用いた)。回遊後, 心地よ いと感じた体験がいつ始まりいつ終わるかをビデオ記録から画定す る。その範囲における記録をもとに, 空間を体験する主体の身体動 作,身体と物的環境との位置関係, 印象などを, 空間体験者自身が体 験を再現できるように文章表現する(これを体験ナラティブと呼ぶ)。 体験主体は自分の体験を自分の身体に結びつけて言語表現できる者 であれば本研究の目的に適合する。本論に報告する空間体験の主体 は第一筆者である。体験ナラティブの中で, 身体動作を示す述部部 分（表 2 の網掛け部分）によって, 空間の場面が切り替わるかどう か判断する。同じ位置でも身体の向きが変わると体験主体の見える ものは変わるので場面が変わると見なす。このようにして, 文章を いくつかの場面に分ける。それぞれの場面の中で, 記述や写真, ビ デオから読み取れる, 体験主体と空間の位置関係を, 図式に示す。

本論で空間体験をした庭園を表 1 に示す。表中の事例番号は空間 体験の識別番号である。また, 体験ナラティブの例（表 1 : 西芳寺 庭園事例（1），表 3 : 西芳寺(1)）を下に示す。

下へ下りる階段がありその先の道が直角に折れている。角の 外側に池が広がり, 内側に樹木に覆われた空間のなかに建物が ひとつある。(場面1) 階段にいるときは両側を木々にはさまれ
表 1 空間体験をした庭園

\begin{tabular}{|l|l|l|l|}
\hline 庭園名称 & 空間体験日時 & 天候 & 事例番号 \\
\hline 西芳寺庭園 & $2013 / 11 / 25$ 9:00 10:30 & 雨/曇 & $(1)(2)(3)(4)(5)$ \\
\hline 慈照寺庭園 & $2013 / 11 / 239: 00 \sim 10: 00$ & 晴 & $(6)(7)(8)(9)$ \\
\hline 等持院庭園 & $2013 / 11 / 2311: 00 \sim 12: 00$ & 晴 & $(10)(11)(12)$ \\
\hline 天龍寺庭園 & $2013 / 11 / 2410: 00 \sim 11: 30$ & 晴 & $(13)(14)$ \\
\hline 六義園 & $2013 / 12 / 1311: 00 \sim 12: 00$ & 晴 & $(15)(16)(17)(18)(19)$ \\
\hline 小石川後楽園 & $2013 / 11 / 0313: 00 \sim 14: 30$ & 晴 & $(20)(21)(22)(23)$ \\
\hline 三溪園 & $2013 / 11 / 02 ~ 14: 00 \sim 16: 00$ & 曇 & $(24)(25)(26)(27)$ \\
\hline 旧芝離宮庭園 & $2013 / 12 / 1511: 00 \sim 12: 00$ & 晴 & $(28)(29)$ \\
\hline 浜離宮庭園 & $2013 / 12 / 1512: 00 \sim 13: 00$ & 晴 & $(30)(31)$ \\
\hline
\end{tabular}

が，高いところから低い方を見下ろ形になるので見通しは良 い。(場面2) 階段を下りて小川が道の下を流れているところで(場 面3)外側の池に首を向け，見るとき，池と自分の間に視界を遮 る木々がなく, 池は上部を覆う木々が少なくなり明るくなるの で，開放感がある。そこで (場面4) 正面に向き直す時に池の隣 の半島を見る。半島は木々が多く目の前に直立するので, 圧 迫感を受けそれ故に閉鎖感がある。(場面5) 進んでいき直角に道 が折れるところから，ここで来た方向からこれから進む方向へ と体を向けると別の池がこれから進んでいく道の外側に見え る。外側にある池と半島と池を見るのに進む距離は曲がって いることで短くて済む。これにより，見る空間の交替が早く なりテンポが良くなると感じるので高揚感を得る。(場面 6) さら に進んで視界を遮る木々がなくなったところで外側の池を园 回。池の方に向くことで, 開放感を得て, 安らぎを得る。

四角で囲った語は身体動作を表している。ここで場面を区切るか どうか判断する（下に何を手がかりに判断したのか記す）。場面を区 切る身体動作を表す語のある部分に下線を引く。直前の下線部中の 身体動作を表す語と同時の動作を表す語がある場合は、場面として 区切らない。同時の動作や経路を表す「進む」が使われている場合 は同一下線部としてよい。場面 3 や場面 4 は，二つの身体動作を示 寸語（場面 3 では「向ける」と「見る」, 場面 4 では「向く」と「見 る」）があるが同時の動作であるため, 一つの場面と判断した。場面 5 と場面 6 も同様に二つの身体動作を示す語（場面 5 では「進む」 と「向ける」, 場面 6 では「進む」と「向く」）があるが,ここでの 「進む」という語は「○○一進む」や「○○まで進む」というよう にある地点まで進んだことを明示寸るのではなく，二つの代表的な 場面間の経路を「進む」という意味で使っているので, ここでは二 つの場面に区切らない。場面 5 の下線部のあとにある「見る」とい う語は, 下線部内の「向ける」という語と同時の動作であるため, 場面に区切らない。場面 6 の下線部のあとの「向く」も同様である。

体験主体と空間との位置関係は, 以下の記法に従って図式表現す る（図 1 ）。空間体験において体験主体の存在は不可欠であるため, 図式の平面図の中央に体験主体を示す円（○）を配置する。円から 伸びる矢印 $(\rightarrow)$ は視線を示す。体験主体が周りの事物を見る際に, 遠近性を意識していると見なし, 体験主体を包含する二重の領域(近 傍・遠隔）を二つの正方形（回）によって示す。正方形としたのは， 後に建築を計画する際に応用し易いと考えたからである。領域の明 るさは空間体験の認識に大きく影響していると考えられるので, 近 傍や遠隔の網掛けの有無によってそれぞれの領域の暗明（二段階） を示す。遠近や明暗は体験主体の認識による相対的なものであり， 絶対的な距離や明るさを示すわけではない。庭園にある木々, 植栽, 建築, 塀, 灯篭などの物体は, 視線を遮るものと抽象化し, 近傍や 遠隔の領域を示寸正方形（口）上に太線で示寸。太線の濃さは視線 
を遮るものの透過性を表し (二段階), 濃い太線は視線を全面的に遮 ることを, 薄い太線は視線を部分的に遮ることを表す。空間体験の 際に主体が事物や空間を注目して見る時，それは主体の空間体験を みる上で重要な要素であると見なし，その注目しているものを星印 (々) で示す。主体が注目していた空間の中まで移行し到着した時, 主体を示寸円（○）の中に星印（引）を入れる。主体のいる地面の 傾斜の有無は, 身体動作に変化を与えるという点で空間体験の重要 な要素であると見なし, 断面図中の主体の下の線の傾きによって主 体のいる面の傾斜を示寸。近傍の領域・前方遠隔の領域・後方遠隔 の領域内の線の傾きによって, 地面の傾斜を平坦・上り坂（右上が り）・下り坂（右下がり）の三段階で示す。

\section{手順 2：空間体験のグルーピング}

体験ナラティブに現れる単語の有無を要素とするべクトルを構成 し（体験ナラティブ中にある語が現れた場合にその語を表す要素を 1 とし, 現れなかった場合は 0 とする), 個々の体験ナラティブの特 徵の抽象表現と寸る。本研究では, 計量テキスト分析のために制作 されたフリーソフトウェア「KH Coder」を用いて行う。体験ナラ ティブに使う単語は, 動詞, 名詞, 形容詞, 副詞, 形容動詞とする。 動詞は, 身体の動作や状沉の変化などを表すので空間体験の分析に 必要である。動詞 B (平仮名の動詞) も含める。名詞は, 主体の経 験は周りの事物などを表し, 空間体験に大きく影響しているので必 要である。名詞は, サ変名詞, 副詞可能, 名詞 B (平仮名の名詞), 名詞 C（漢字一文字の名詞）を含むが, 固有名詞, 組織名, 人名, 地名は含めない。副詞可能は主に時相名詞なので空間体験の言葉に 必要である。形容詞, 形容動詞は, 事物がもつ何らかの属性を示し たり, 事物を限定したりするので空間体験の分析には必要である。 形容詞 B (平仮名の形容詞) も同様の理由で含める。副詞は, 程度 や状態を表すので空間体験の分析に必要である。副詞 B (平仮名の 副詞）も同様の理由で含める。否定助動詞は, 否定を表す助動詞の ことで特に「見えない」という表現が多かったが，「見えない」こと は空間体験の分析に必要であるので含める。分析に使用する単語は, 各体験ナラティブの中での出現数が 2 回以上のものとする。これは, 出現数が 1 の単語はグルーピングする際に重要ではなく, 出現数が 20 単語の中に身体性を表し空間体験に重要と思われる単語(「振り 返る」など）が含まれていたからである。Jaccard 係数（一つの事 例に含まれる語の数が少なく, それぞれの語が一文書中にしか現れ ない場合に有効で, 例えば, 語 A と語 B のどちらも含まない事例が 多くあったとして，それによって無意味に A，Bの係数が大きくな らないという性質がある）を特徵間の距離とみなし, 体験ナラティ ブをクラスタリングする（Ward 法を用いる）。

手順 1 で示した西芳寺(1)を例に体験ナラティブに現れる語を抽出 すると，「外側」「木々」「階段」「半島」「空間」「視界」「方向」「開 放」「直角」「見る」「進む」「得る」「下りる」「向く」「向ける」「遮 る」「折れる」「覆う」「良い」「ある」「なる」「これから」「池」「道」 「下」の全部 25 語となる。表 3 に示す 31 ヶ所の体験ナラティブに 現れる語は全部で 238 語となる（表 1 )。西芳寺(1)の特徴を表す心゙ クトルは, 上記の 25 次元で 1 を要素に持ち、残りの 213 次元で 0 を要素に持つ。体験ナラティブごとに, 語の出現回数を要素とする 238 次元のベクトルを構成し, 体験の特徴を表すデータとみなし, jaccard 係数を用いて類似度を測る。

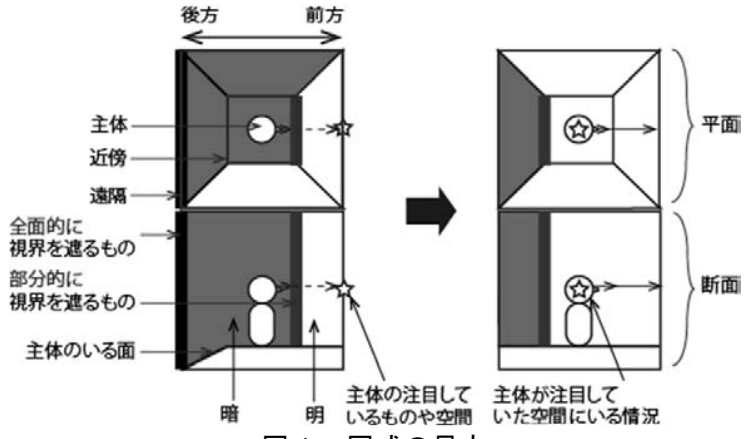

図 1 図式の見方

表 2 体験ナラティブの特徴づけに用いた 238 語

\begin{tabular}{|c|c|c|c|c|c|}
\hline 名詞 & 下方 & 山 & 形容詞 & 動詞 & 惹く \\
\hline 木々 & 後ろ & 隣 & 明るい & 進む & 出る \\
\hline 空間 & 向き & 延 & 高い & 見える & 植える \\
\hline 視界 & 周り & 角 & 暗い & 見る & 伸びる \\
\hline 階段 & 書院 & 丘 & 低い & 得る & 生える \\
\hline 建物 & 上空 & 枝 & 大きい & 上る & 生まれる \\
\hline 右側 & 石庭 & 次 & 良い & 向く & 盛り上がる \\
\hline 左側 & 太陽 & 松 & 細い & 曲がる & 折る \\
\hline 正面 & 直前 & 色 & 少ない & 覆う & 迫る \\
\hline 前方 & 内側 & 石 & 多い & 下りる & 落ち着く \\
\hline 安らぎ & 日当たり & 先 & 丸い & 感じる & 流れる \\
\hline 視線 & 背景 & 段 & 広い & 遮る & 外れる \\
\hline 場所 & 池 & 庭 & 赤い & 着く & 曲げる \\
\hline 方向 & 植栽 & 南 & 形容詞B & 渡る & 近づく \\
\hline 東屋 & 中島 & サ変名詞 & ない & 行く & 見上げる \\
\hline 部分 & 小川 & カーブ & いい & 現れる & 見渡せる \\
\hline 景色 & 日の光 & 開放 & よい & 向ける & 降り注ぐ \\
\hline 外側 & 名詞B & 高揚 & 形容動詞 & 近づく & 使う \\
\hline 手前 & まわり & 蛇行 & 直角 & 驚く & 終わる \\
\hline 上部 & 名詞C & 閉鎖 & 緩やか & 差し込む & 植わる \\
\hline テンポ & 道 & 満足 & 自然 & 折れる & 振り向く \\
\hline 回廊 & 左 & 圧迫 & 神聖 & 入る & 振り返る \\
\hline 段差 & 奥 & 接近 & 丁寧 & 開ける & 生い茂る \\
\hline 地面 & 右 & 建築 & 変 & 続く & 占める \\
\hline 飛び石 & 橋 & 紅葉 & 副詞 & 囲む & 眺める \\
\hline 両側 & 川 & 移動 & 少し & 変わる & 聞こえる \\
\hline 右前 & 目 & 達成 & 再び & 来る & 歩く \\
\hline 心字池 & 塀 & 注意 & 最も & 刈り込む & 動詞B \\
\hline 半島 & 上 & 安心 & 段々と & 挟む & ある \\
\hline 方丈 & 島 & 持続 & 一度 & 消える & なる \\
\hline 本堂 & 横 & 一望 & 副詞B & 照らす & する \\
\hline 木漏れ日 & 体 & 反射 & やや & 離れる & いく \\
\hline 垣根 & 背 & 反対 & すぐ & 囲う & できる \\
\hline 驚き & 影 & 分岐 & そのまま & 見渡す & いる \\
\hline 隙間 & 下 & 副詞可能 & だんだんと & 広がる & なくなる \\
\hline 最初 & 首 & 前 & ほぼ & 持? & くぐる \\
\hline 自分 & 木 & 一部 & これから & 受ける & みる \\
\hline 斜め & 音 & 全体 & さっき & 登る & ずれる \\
\hline 樹木 & 水 & 二番 & さらに & 引く & 否定助動詞 \\
\hline 水面 & 滝 & 近く & だんだんと & 沿う & ない \\
\hline 日陰 & 門 & 今 & まず & 開 $<$ & ぬ \\
\hline 屋根 & 光 & 多< & やがて & 向かう & \\
\hline
\end{tabular}

注 網掛けは身体動作を示すと考える動詞である。

\section{手順 3：空間体験の核図式の作成}

核図式は同じグループに属する空間体験に共通する体験主体と空 間の関係を示寸図式である。手順 2 の操作によって同一クラスター に属する図式に一致する要素を核図式の要素とする(図 2)。ここで, 明暗 (図式上のアミの有無)が異なることは薄いアミによって示す。 また，視界を遮るものに部分的か全体的かの違いがあるときは部分 的遮蔽を共通要素とする。

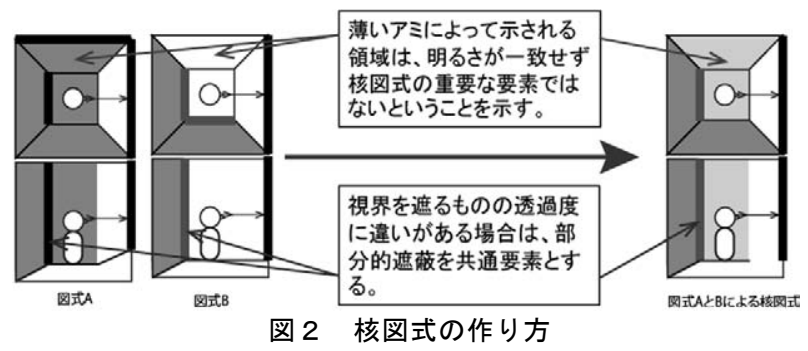




\section{4. 結果と考察}

表 1 に示す日本庭園を「心地よい空間」というテーマを意識して 回遊し, テーマに関連する 31 の空間体験（表 3 ）をした (手順 1 )。 これらの空間体験の図式表現 (手順 1 )をグルーピングし(手順 2), 核図式を作成した（手順 3 )。図 10 に空間体験をした庭園の平面図 を示す。図 11 に, 個々の空間体験の図式, デンドログラム, 各グ ループの核図式を示す。

31 個の空間体験の図式表現から 30 個の核図式を作成することが できる。まとまりとして適度と思われ, また, 空間体験全体をカバ

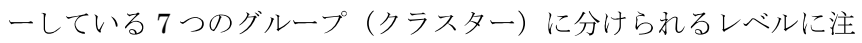
目して各グループに属する空間体験に共通する特徴を以下に示す。 加えて, いくつかのグループの核図式と個々の空間体験の実感を比 較して, 有効性について検討する。

\section{表 3 各空間体験の概要}

\begin{tabular}{|c|c|c|}
\hline \multicolumn{2}{|c|}{ 事例番号 } & 事例番号の指す位置の説明 \\
\hline (1) & 西芳寺(1) & 本堂から池に向かって階段を下りて曲がり中島を見る \\
\hline (2) & 西芳寺(2) & 湘南亭に最接近し，そこから池に向かう \\
\hline (3) & 西芳寺(3) & 湘南亭から順路に沿って潭北亭へ向かう \\
\hline (4) & 西芳寺(4) & 潭北亭を出たところから向上関へ向かう \\
\hline (5) & 西芳寺(5) & 向上関から指東庵に最接近する \\
\hline (6) & 慈照寺(1) & 中門をくぐって向月台の方へ向かい銀閣をみる \\
\hline (7) & 慈照寺(2) & 敷石遺跡の場所から階段を上って銀閣の庭園を俯瞰する \\
\hline (8) & 慈照寺(3) & 山を下りて池越しに銀閣をみる \\
\hline (9) & 慈照寺(4) & 出ロへ向かい銀閣が目の前に現れる \\
\hline (10) & 等持院 (1) & 書院脇の飛び石を進み階段を登って清蓮亭の前まで行き振り返る \\
\hline (11) & 等持院(2) & 清蓮亭から心字池の方へ行く \\
\hline (12) & 等持院(3) & 心字池沿いの道を進み中島に入る \\
\hline (13) & 天龍寺(1) & 入りロから大方丈の奥に見える曹源池庭園をみる \\
\hline (14) & 天龍寺(2) & 小方丈の方から池に向かう \\
\hline (15) & 六義園(1) & 藤波橋を渡って高台へ上り渡月橋を眺める \\
\hline (16) & 六義園(2) & 藤代峠を登る \\
\hline (17) & 六義園(3) & 山陰橋からツツジ茶屋へ行く \\
\hline (18) & 六義園(4) & 滝見の茶屋へ行く \\
\hline (19) & 六義園(5) & 出汐の湊から心泉亭へ行く \\
\hline (20) & 後楽園(1) & 小盧山から大堰川へ行きそこを渡る \\
\hline (21) & 後楽園(2) & 小盧山へ行き，庭園を眺める \\
\hline (22) & 後楽園(3) & 内庭から延段を通る \\
\hline (23) & 後楽園(4) & 大泉水から竹生島を横目に内庭へ行く \\
\hline (24) & 三渓園(1) & 松風閣の方から三重塔の目の前まで行く \\
\hline (25) & 三渓園(2) & 旧燈明寺本堂から正門に向かう道で観心橋が左に現れる \\
\hline (26) & 三溪園(3) & 内苑に入り，臨春閣，月華殿をみる \\
\hline (27) & 三渓園(4) & 観心橋の方から八つ橋を渡る \\
\hline (28) & 旧芝離宫(1) & 園路の中の松の木の下に入る \\
\hline (29) & 旧芝離宫(2) & カキツバタやショウブの植わる蛇行する道を通って東屋へ行く \\
\hline (30) & 浜離宮 (1) & 馬場跡から高台を登って池を眺める \\
\hline (31) & 浜離宮(2) & 汐留川の脇の道を進む \\
\hline
\end{tabular}

体験主体の側方近傍に視界を遮る物がある場所から移行し, 前方 遠隔の空間に注目寸る。その空間へ移行し前方の明るい空間を見る。 (17) 六義圆( $(3)$ 山陰橋からツツジ茶屋へ行く

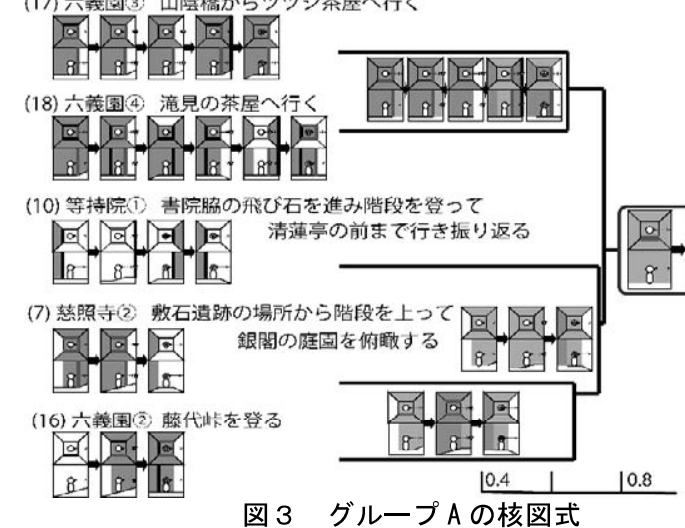

六義園(4)の例では，まず近傍側方の視界を遮る植栽に注目し（写 真 $1-\mathrm{a}$, 図 3-A1), 進んでいくと道の左側の植栽が低くなり前方 遠隔に建物の屋根を注目して見る（写真 $1-\mathrm{b}$, 図 3-A2）。屋根以 外は見えず，どのような空間であるのか気になり行ってみる。東屋 の目の前を川が流れており,この東屋に入って座って休㮩するとき， 左には滝が，右には池が見え（写真 $1-\mathrm{c}$, 図 $3-\mathrm{A} 3$ ), それらの明 るい空間を落ち着いた安らぎある空間から見ることで心地よいと感 じる。

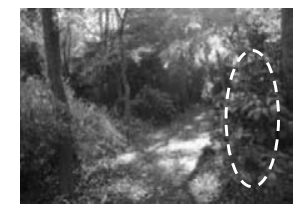

(a)

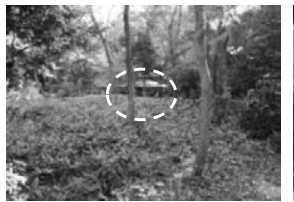

(b)

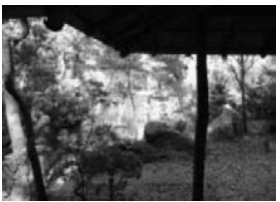

(c)
写真 1 六義園(4)

グループ A では, どの体験も明るさの変化が空間体験での心地よ さに影響していたという実感があるが，核図式にはほとんど現れて いない。単語の想起頻度だけでなく, 順序も考慮したグルーピング をするか方向性を問わない変化を図式に明記することで単なる明る さの変化だけでなく同じ方向の変化をグルーピングできると考える

\section{4-2グループB}

体験主体が遠隔から注目していた場所へ移行する。後方近傍に視 界を遮るものがある。 (31) 浜離宮(2)

(12) 等持院(3)

(23) 後楽園 4

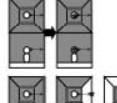

28) 旧芝離宮 1 8. 19.10

(28) 旧芝離宮1

(15) 六義園(1) iil int

(30) 浜離宮 (1)
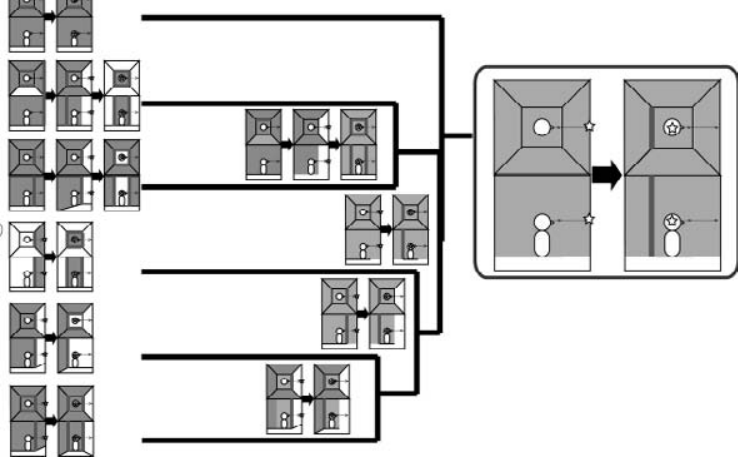

図 4 グループ B の核図式

（28）旧芝離宮(1)の例では，島の中にある松の木で日陰になった 空間にベンチが置かれている様子を見てその空間に注目寸る（写真 2-a，図 4-B1)。注目した空間に入って実際にベンチに座ってみ る（写真 $2-\mathrm{b}$, 図 4-B2) と，松の枝が横に伸びているので視界 の方が見えにくくなり，視線は下にある島や池にいく。視線の先の 空間は自身の近傍よりも明るい空間となっており，これらの明るい 空間を暗く落ち着いた閉鎖感のある場所から座って見渡すことがで き，安らぎを得て心地よいと感じる。

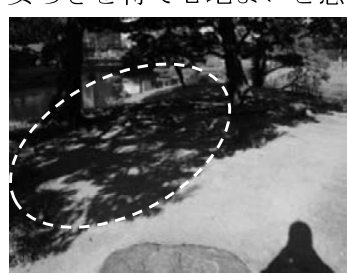

(a)

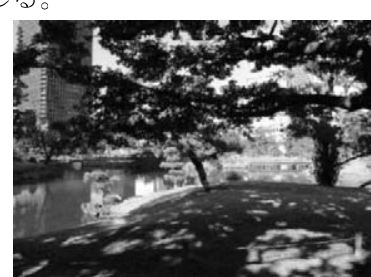

(b)
写真 2 旧芝離宮 1 
グループBでは, 体験の核となる, 注目していた空間へ到着する, が図式で抽出されている。さらにその空間は近傍に視線を遮るもの があることが抽出されており，これがあることで安心感を生んでい ると考えられる

\section{4-3グループC}

体験主体が到着した場所から注目する対象を遠隔に見る。移行前 は主体の右側近傍に視界を遮るものがあり，移行後は前方近傍に部 分的に視界を遮るものがある。

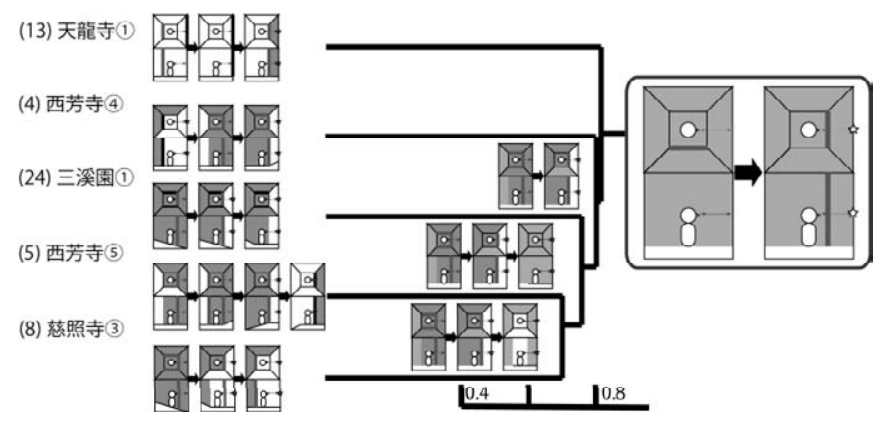

図 5 グループCの核図式

（5）西芳寺(5)の例では，右側近傍に視界を遮る木々がある（写真 $3-\mathrm{a}$, 図 5-C1）道を曲がった時, 前方遠隔やや上方に明るい空 間が見える (写真 $3-\mathrm{b}$, 図 5-C2)。前方近傍にある木々が部分的 に視界を遮っている。この奥の空間は日が当たることで紅葉した 木々が鮮やかであり，この奥の空間に神聖さを感じる。

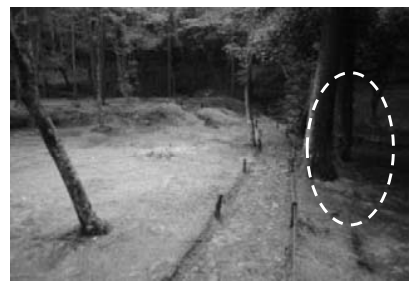

(a)

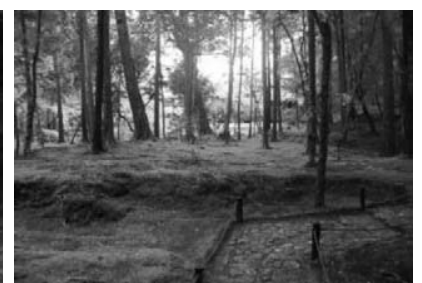

(b)
写真 3 西芳寺(5)

グループ C は，場面が変わる（図 $5-\mathrm{C} 1 \rightarrow \mathrm{C} 2$ ）ことで遠隔に注 目するものを見て心地よく感じるという図式が抽出できている。し かし, グループ A 同様に, 前方遠隔の明るさの変化が影響していた ということが図式に上手く現れていない。

\section{4-4グループD}

体験主体が移行することで, 前方の明暗が明 $\rightarrow$ 暗 $\rightarrow$ 明と変化する。 最後は，前方だけでなく主体の近傍も明るい。

(2) 西芳寺(2)

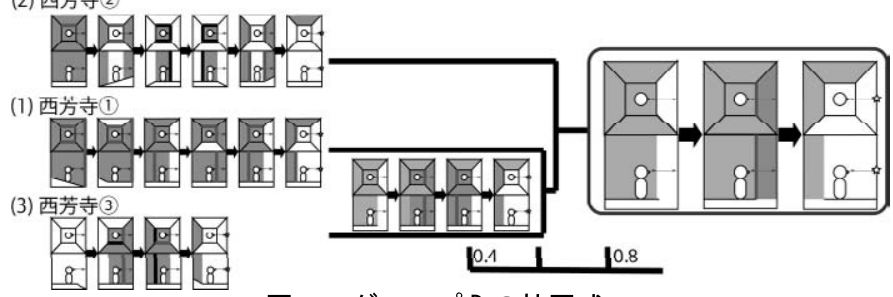

図 6 グループDの核図式

（3）西芳寺(3)の例では，はじめ池という明るい空間を見ていて
(写真 4-a, 図 6-D1), その池に最接近して開放感を得るという ものであるが，途中で目の前に視界を遮るものが来ることで前方が 暗くなる (写真 $4-\mathrm{b}$, 図 6-D2)。これにより最後目の前が開けた とき（写真 $4-\mathrm{c}$, 図 6-D3) に開放感が大きく心地よいと感じる。

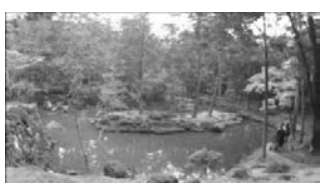

(a)

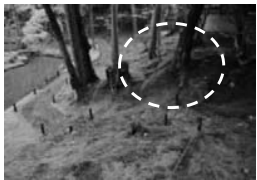

(b)

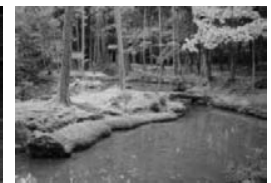

(c)
写真 4 西芳寺(3)

場面が切り替わることで前方の明るさの変化が影響し心地よさを 生むことが図式に抽出されている。前方が明るい空間（図 $6-\mathrm{D} 1$ ) から前方がより明るい空間（図 6-D3）に移行寸る際に, 間に一旦 前方が暗い空間（図 6-D2）を挟むことで場面がはっきりと分かれ て空間が分節化され多層化する。これにより心地よさが生まれてい ると考えられる。

\section{4-5グループE}

体験主体の近傍は暗く前方のみ明るい空間から移行し，近傍と前 方が明るくなる。

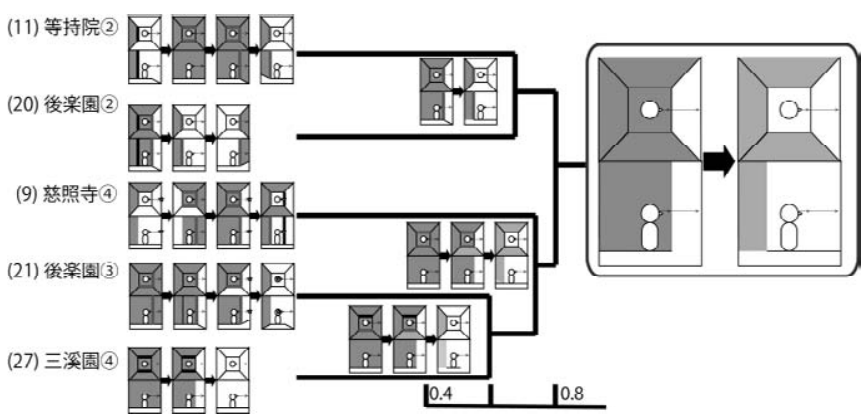

図 7 グループE の核図式

（21）小石川後楽園(3)の例では，暗い曲線状の道を進んでいると 前方遠隔に明るい空間が見える（写真 $5-\mathrm{a}$, 図 $7-\mathrm{E} 1)$ 。進んでい くとその場所に到着し自身の近傍も明るくなる (写真 $5-\mathrm{b}$, 図 7

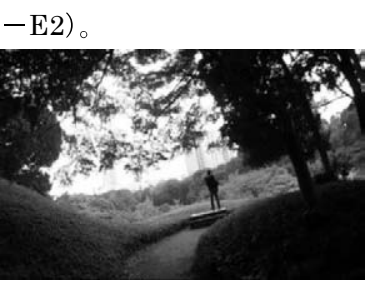

(a)

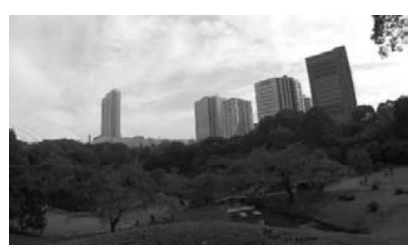

(b)
写真 5 小石川後楽園(3)

グループ E では，茂みに覆われ近傍しか見えなかったが，そこを 抜けると遠隔のものが見える明るい空間に着く,という実感がある。 しかし，見ているものの距離感が伸びたことが図式には現れていな い。視線の矢印の長さを变えるなどして表現する必要がある。

\section{4-6グループ F}

主体の前方と側方に注目するものがあり前方の注目するものを見 て移行する。交互に注目するものが現れる。 


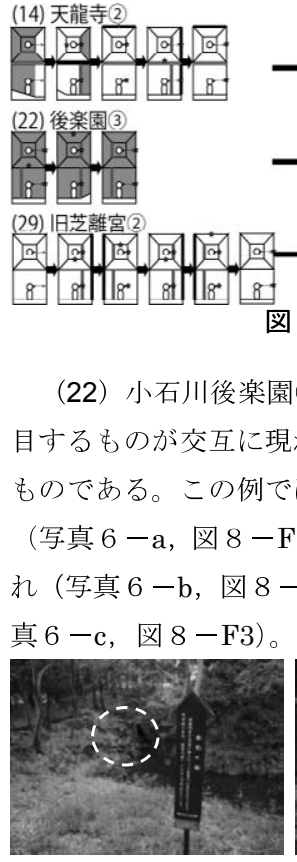

(a)

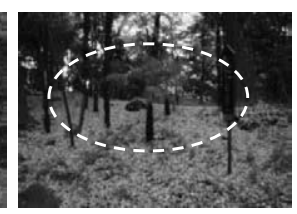

(b)

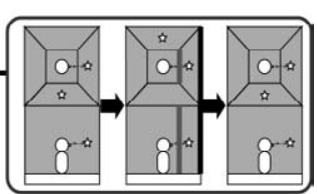

10.8

図 8 グループFの核図式

写真 6 小石川後楽園(4)

蛇行する道の形状によって身体の向きが操作され, 向きを変えた 時に注目するものが現れるようにすることで場面が切り替わる。こ うすることで, 空間が分節化され多層化し, 短い距離でテンポよく 場面が切り替わる（図 $8-\mathrm{F} 1 \rightarrow \mathrm{F} 2 \rightarrow \mathrm{F} 3$ ) という心地よさを生み出 していると考えられる。

\section{4-7 グループ G}

近傍のものが視界を邪魔して側方遠隔のものが見えず，移行する と前方遠隔に見える。

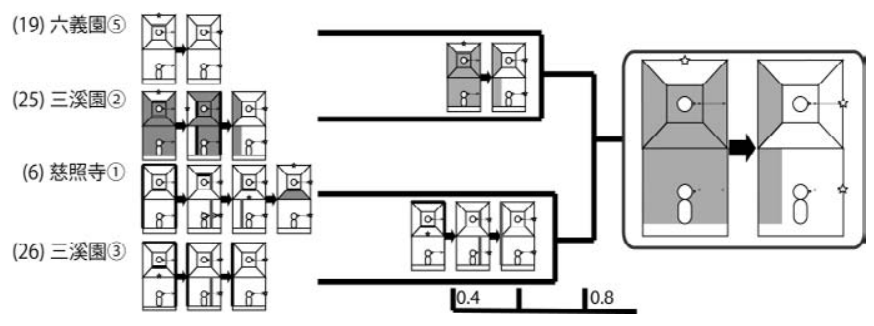

図 9 グループ Gの核図式

（26）三溪園(2)の例では，池の横の木々に覆われた道を歩いてい て (写真 7-a, 図 9-G1), 左側に橋が現れ視界が開けたところで 左を向くと前方遠隔に三重塔が見え (写真 $7-b$, 図 9-G2), 突然 の登場に驚くというものである。

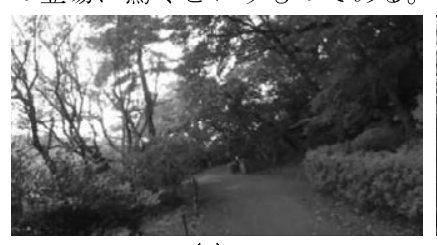

(a)

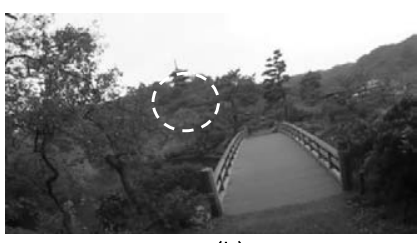

(b)

写真 7 三溪園2

場面が切り替わる（図 $9-\mathrm{G} 1 \rightarrow \mathrm{G} 2$ ）と注目するものが現れると いうことが図式に現れている。同時に近傍が明るいことが抽出され

ているが，これは図式を見るまで気がつかなかったことである。近 傍と前方がともに明るいことで，それらの空間を一体として捉え， 遠隔にあるものに注目することができた（図 9-G2) と考えられる。

\section{4-8＼cjkstart核図式の活用}

核図式を持って庭園を再度歩き,核図式を意識しながら行動した。 対象とした庭園は小石川後楽園で 2014 年 2 月 18 日 14〜15時である。 核図式を意識しながら歩くことで空間体験が少し豊かになったと実 感していることが二つあるので以下に示す。

一つ目は意識的に明るさに注目寸るようになる。具体的には，大 泉水の隣の木洩れ日空間の中にいるときにグループ E の核図式を意 識する。光が差し込んでいる空間を探して移動し，そこから前方に 見える明るい池を遠目に眺好とき冬の柔らかい光に包まれた状態 となり心地よいと感じた。この場所は普段であれば何も考えずに通 り過ぎていたが, 核図式を意識することで明るさの変化に注目した。 二つ目は意識的に近傍と遠隔を注目するようになる。大泉水の中 島を眺めながら移動し，木ヶが手前に現れるようになる。中島より も近傍にあるその木々に注目してみることでそれらの作り出す日影 空間を意識するようになる。このあと，グループ D の核図式を意識 して明るいところへ移動し再び明るい池の方を眺める。このように 近傍と遠隔を意識することで，空間の切り替わりが多くなりテンポ の良さを感じる。普段であればただ遠隔に見える中島を眺めながら 歩くだけだが，核図式を意識することで近傍遠隔に注目した。

このように，得られた核図式を意識してみることでそれまで気付 かなかった心地よさを得ることができたが，このことは得られた核 図式が心地よいと感じる空間の図式として有効なものであることを 示唆している。また，核図式を意識することで空間体験が豊かにな る可能性がある。

\section{5. 今後の課題}

上記 $7 つ の$ 核図式と空間体験時の実感との比較から図式表現の改 善課題を記す。明から暗，暗から明という方向性を問わない明暗の 変化を図式表現する, 女るいは順序を考慮したグルーピングをする。

31 個の事例から全体の核図式を作成したときに共通寸る要素は 一つも残らず実感として物足りない印象がある。図式を作成する際 の変数を多くすることで核図式を作成しても要素が残りやすくなる ため，例えば視線を遮るものの高さを三段階（目線より上・下・目 線と同じ)にするというようにして変数を増やしていく必要がある。

また，体験ナラティブから図式化するルールを決め体験主体でな い人が図式化できるようにすることで，複数の人の図式を同じルー ルで作ることができ，客観性のある「心地よい空間」の核図式を得 ることができると考えられる。

\section{6. まとめ}

空間体験を身体性に注目して図式表現し, 空間体験の図式に共通 する要素に注目することによって, 空間体験の特徴を核図式として 表現した。庭園の心地よいという空間体験のメカニズムの表現する 核図式を用いることによって，庭園空間の理解と説明が可能となる ことを確認した。図式と実感との差異を縮める方法を考案すること が今後の課題である。 

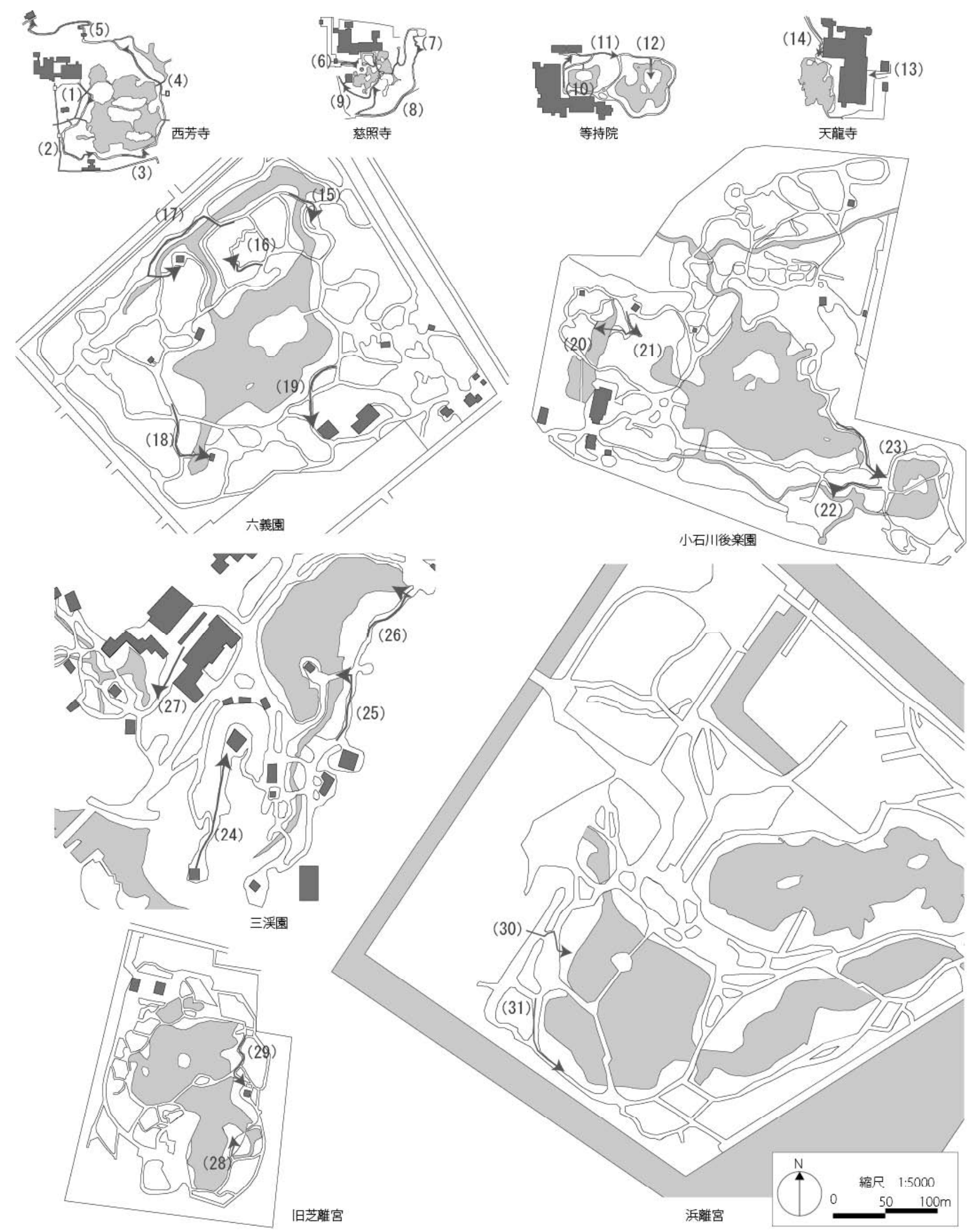

旧芝離宮
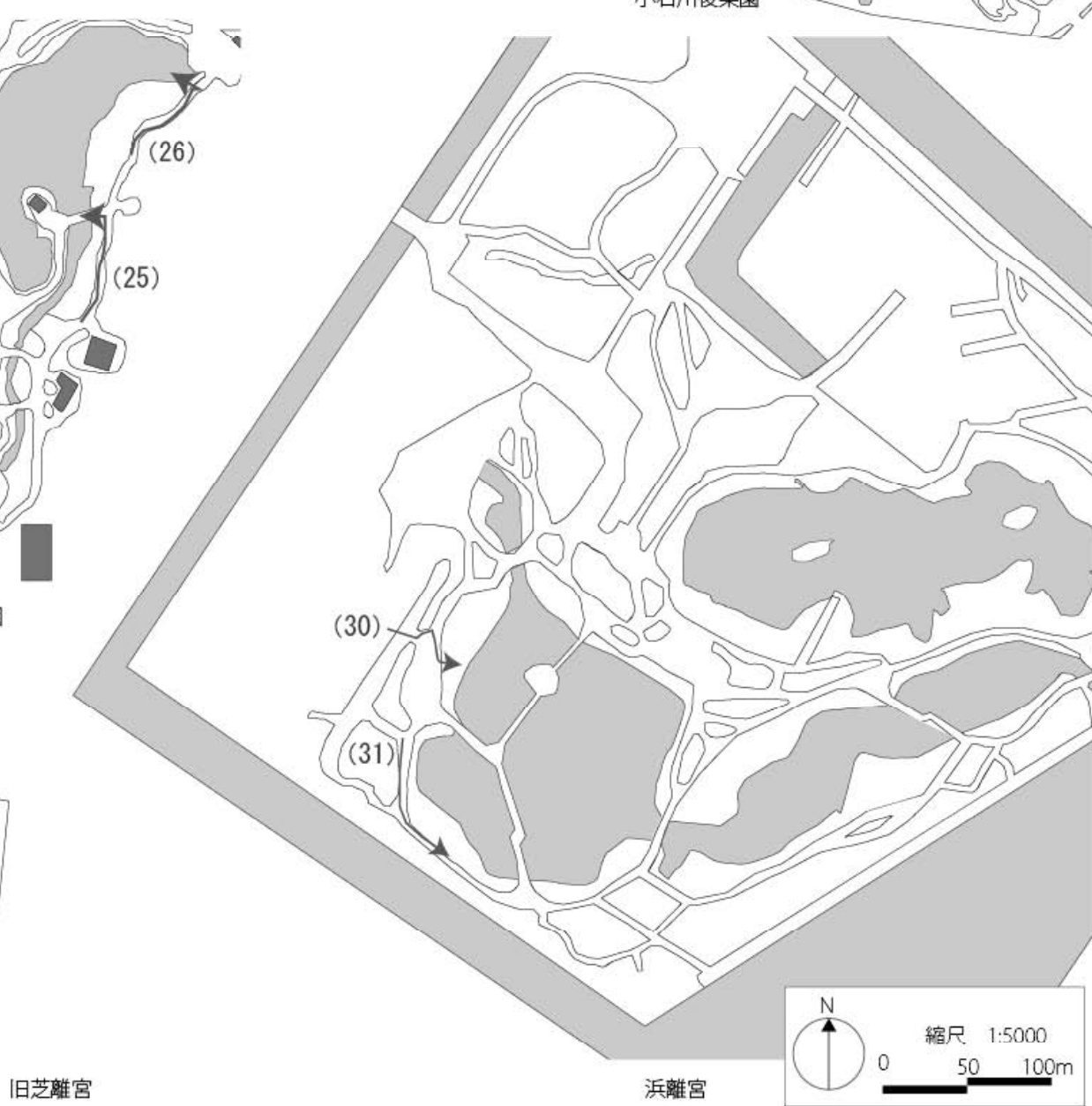

図 10 調査対象とした全ての庭園の平面図

注 西芳寺・慈照寺・後楽園・六義園・天龍寺は『日本の庭園文化』6)，等持院は『庭園から都市へ』7) に基づいて作成，

三溪園は三溪園公式 HP の園内案内地図に基づいて作成, 旧芝離宮・浜離宮は東京都公園委員会 HP の園内マップに基づいて作成） 
グループ1

体験主体の側方近傍に視界を 遮る物がある場所から移行し 前方遠隔の空間に注目する。 その空間へ移行し前方の明る い空間を見る。

\section{グループ2}

体験主体が遠隔から

注目していた場所へ移行する。 後方近傍に視界を遮るものがある。

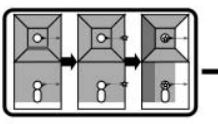

グループ3

体験主体が到着した場所から注目 する対象を遠隔に見る。移行前は 主体の右側近傍に視界を遮るもの があり，移行後は前方近傍に部分 的に視界を遮るものがある。

$$
\text { グループ4) }
$$

体験主体が移行することで， 前方の明暗が明 $\rightarrow$ 暗 $\rightarrow$ 明と 変化する。最後は， 前方だけでなく主 体の近傍も明るい。

\section{グループ(5)}

体験主体の近傍は暗く 前方のみ明るい空間から移行し， 近傍と前方が明るくなる。

グループ6

主体の前方と側方に注目 するものがあり前方の 注目するものを見て移行

する。交互に注目するもの が現れる。

\section{グループ 7}

近傍のものが視界を邪魔して

側方遠隔のものが見えず， 0.4 移行すると前方遠隔に見える。
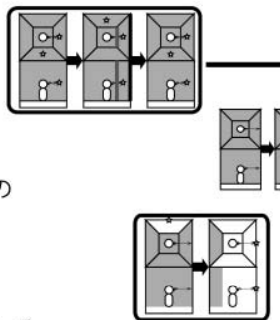

図11７つのグループから全体の核図式が出来るまでのデンドログラム
11）宮岸幸正，材野博司：シークエンス景観における景観行動と空間の開放 度・インパクト度との関係, 日本建築学会計画系論文報告集, No.440 pp.119-125, 1992.10

12）諏訪正樹：身体的知覚ツールとしてのメ夕認知的言語化,人工知能学会 誌,Vol.20,No.5,pp.525-532,2005

\section{参考文献}

1）材野博司, 宮岸幸正 : 基本構造シークエンス景観と行動シークエンス景 観との関係, 日本建築学会計画系論文報告集, No.438, pp.79-85, 1992.8

2）横山勝樹，高橋鷹志：空間図式の研究，その $1 .<$ 場所>の概念による空 間図式のモデル化, 日本建築学会計画系論文報告集, No.395, pp.19-30, 1989.1

3) 横山勝樹, 高橋鷹志: 建築図面の解釈にみられる論理構造の分析, 空間 図式の研究 その 2 , 日本建築学会計画系論文報告集, No.420, pp.7-15, 1991.2

4）横山勝樹，今井ゆりか，高橋 鷹志：建築空間の認知における方位概念 の考察, 空間図式の研究 その 3 , 日本建築学会計画系論文報告集, No.448, pp.81-89, 1993.6

5）ノルベルグ・シュルッ：実存・空間・建築，鹿島出版会， 1973.9

6） シール・フィリップ,大野隆造,小林美紀 : 行動経路セッティングのシー クエンスデザイン, 人間・環境学会誌 6(1), 19-28, 2000.5

7）ジョージ・レイコフ：認知意味論,紀伊國屋書店,1993

8) Philip Thiel : PEOPLE, PATHS, and PURPOSES Notation for a Participatory Envirotecture, University of Washington Press, 1997

9）西桂：日本の庭園文化, 京都：学芸出版社, 2005

10）材野博司：庭園から都市へ シークエンスの日本, 鹿島出版会, 1997 


\title{
STUDY ON GRAPHICAL REPRESENTATION OF SPACE EXPERIENCE FOCUSING ON THE PHYSICALITY
} Hayato FUKUDA* and Haruyuki FUJII**

\author{
* Graduate Student, Dept. of Architecture, Tokyo Institute of Technology \\ ** Prof., Dept. of Architecture, Tokyo Institute of Technology, Dr. Eng.
}

The objective of this study is to represent the characteristic of the experience of space, such as a building or a garden, by the graphical expression of the schema framing the space. Particularly, we pay attention to the relations between the space and the person who experience there. The extracted characteristic of the experience of space would be able to be applied to new space design. And, we should be able to understand and explain the experience of space by the schema. This paper proposes a method of schematizing the characteristic of the experience of space and the schemata that are extracted from the experiences of the cozy garden sequence by using this method.

The outline of the method of schematizing is following: First, we experience some place, take steal and motion pictures that represent our special experience, and make narratives describing what we feel there and how the relations among our body as well as mind and the significant elements organizing the space. We extract a schema from the sentences composing the narratives (procedure 1). Then we group the schema of individual space experience with respect to the similarity of the sentences, i.e., the number of the words appeared in sentences (procedure 2). Extract the elements of the schema which are common to every group (call this kind of schema as "nuclear schema"); (procedure 3). Finally, we examine the effectiveness of the nuclear schema. This method involves the following research question.

Procedure 1: How to describe schemas expression of the space experience?

Procedure 2: How to group the space experience?

Procedure 3: How to make nuclear schemas?

The following results were obtained: First, we experienced 9 gardens, and made 31 narratives and as many schemata. Then we grouped the schemata and made 30 nuclear schemata. Finally, we found that the nuclear schemata made us understand and explain the places easily.

In conclusion, we represented the characteristic of the experience of space as a nuclear schema and ascertained the effectiveness of the nuclear schema. 